\title{
THE THEORY AND PRACTICE OF CONSTITUTIONAL REFORM*
}

\begin{abstract}
PETER W. HOGG**
Recent developments in Canadian constitutional law have stimulated a great deal of debate and controversy over the value and content of constitutional reform. Areas in which such reform could be carried out include the division of powers, central institutions, a charter of rights and patriation and amendment procedures. The author discusses these areas in the context of the forces he perceives to be motivating the present trend in favour of constitu. tional change. He also provides a discussion of the present reform process and concludes with an overview of the reform mechanism which he would like to see implemented.
\end{abstract}

\section{IS CONSTITUTIONAL REFORM NECESSARY?}

The major forces propelling the movement for constitutional reform in Canada are French-Canadian nationalism and western regionalism. ${ }^{1}$

French Canadians are a minority in the nation as a whole, but a majority in the province of Quebec. The French language and the cultural attributes which tend to cling to a language have made the French Canadians a distinctive people. This distinctiveness, nurtured by the memory of the conquest by the English and the constant danger of assimilation, has made them anxious to be masters in their own house. At one extreme this involves a separate nation in the territory of Quebec. But for those French Canadians in Quebec who are not separatists it has led to demands for greater power in the provincial government in Quebec City - the government which is controlled by a French-Canadian majority.

Western regionalism is not based on a distinctive language or culture, but on the distinctive economic base of the four western provinces. Their economies depend upon primary production - of grain, metals, wood, pulp, and, of course, oil and gas. Because the bulk of Canada's population is concentrated in Ontario and Quebec, federal policies have tended to favour the manufacturing industries and the consumers of central Canada. This tendency is reflected in the tariffs which protect domestic manufacturing, in transportation policies, and most recently and dramatically, in federal control of the price of oil and gas. A logical response by western Canadians has been to seek to reduce the power of the central government which they cannot control and to enhance the powers of the provincial governments which they can control.

It is obvious that the forces of French-Canadian nationalism and western regionalism will have to be accommodated if the country is to stay together. What is not so obvious is that this accommodation needs to take the form of

* This article is a revised version of the Clinton J. Ford lecture, which was delivered at the University of Alberta on February 12, 1981. It was prepared while I was a visiting professor in the law faculty of the University of Victoria, Victoria, B.C.. I am very grateful to my colleagues there, Professors Ronald I. Cheffins and James C. MacPherson, who each read an earlier draft of the paper and made extensive and helpful criticisms of it.

- Professor of Law, Osgoode Hall Law School, York University, Toronto.

1. For excellent recent diagnoses of Canada's constitutional ills, see K. M. Lysyk, "Reshaping Canadian Federalism" (1979) 13 U.B.C. L. Rev. 1; Paul C. Weiler, "Confederation Discontents and Constitutional Reform" (1979) 29 U. Toronto L.J. 253; The Task Force on Canadian Unity, A Future Together (1979). 
constitutional change. It must be remembered that there have been several major shifts in the balance of power since Confederation which were not accompanied by changes in the formal constitutional instruments. ${ }^{2}$ One may reasonably conclude that constitutional reform may not be necessary to accommodate Canada's dualist and regional forces. However, that is not the conclusion which has been reached by the various groups which have recently made official studies of the constitution. Each of them has recommended constitutional reform. ${ }^{3}$

There are other, less pressing, reasons for seeking constitutional change. First, there is the idea that Canada should rid itself of the remaining vestiges of its colonial past. The most obvious measure to this end is the "patriation" of the constitution, ending once and for all the British power to legislate for Canada. As well, obsolete portions of the British North America Act could be repealed, its name changed, and some modernization of language attempted. Secondly, and related to the first point, Canada should insert a domestic amending formula into its constitution not only so that amendment can take place without recourse to the United Kingdom but so that the respective roles of the federal and provincial governments and the voters in the amending process should be clearly defined for the first time. Thirdly, there is the impulse to protect the civil liberties of individuals through the inclusion of a charter of rights in the constitution. ${ }^{4}$ Fourthly, even granting the necessity in general for increased provincial powers, there is a strong case for

2. See P. W. Hogg, Constitutional Law of Canada (1977), chs. 3,4.

3. The recent studies, to which reference will be made in this article, are as follows:

Victoria Charter (1971).

Special Joint Committee of the Senate and House of Commons of Canada, Report on the Constitution of Canada (Canada, 1972).

Ontario Advisory Committee on Confederation, First Report (April 1978), Second Report (March 1979) (Toronto).

Government of Canada, A Time for Action: Toward the Renewal of the Canadian Federa. tion (June 1978) and Bill C.60 (June 1978).

Canadian Bar Association Committee on the Constitution, Towards a New Canada (Canadian Bar Association, August 1978).

Government of British Columbia, British Columbia's Constitutional Proposals (Province of British Columbia, September 1978).

Government of Alberta, Harmony in Diversity: A New Federalism for Canada (Province of Alberta, October 1978).

Western Premiers Task Force on Constitutional Trends, First Report (May 1977), Second Report (April 1978), Third Report (March 1979).

The Task Force on Canadian Unity, A Future Together (Minister of Supply and Services, Canada, January 1979).

The Constitutional Committee of the Quebec Liberal Party, A New Canadian Federation (The Quebec Liberal Party, Montreal, Quebec, January 1980).

Proposed resolution for enactment of the Constitution Act, 1980.

A 43-page summary of the recommendations of these studies has been prepared by the author's research assistant, Elizabeth A. Brown. It is available on request and upon payment of photocopying costs.

4. At the time of writing (March 1981) the federal Parliament is debating a resolution for a joint address to the United Kingdom government requesting the enactment by the United Kingdom Parliament of a set of amendments to the Canadian constitution, including its patriation, the adoption of an amending formula, and a charter of rights. The legality of the proposed resolution has been challenged by six provincial governnments in the courts of Manitoba, Quebec and Newfoundland, on the basis that the proposed amendments have not been agreed to by a majority of provinces. 
the enlargement of certain federal powers to enable effective national action in some areas of economic policy where federal power is lacking or unclear or present only in an emergency, for example, competition policy, foreign ownership, securities regulation and wage and price controls.

Arising from all these various impulses the following areas of constitutional reform require consideration: (1) the division of powers; (2) central institutions; (3) a charter of rights; and (4) patriation and amendment. A final section of the paper will examine the reform process.

\section{DIVISION OF POWERS}

As noted earlier, the most obvious way to redress the grievances of French Canadians and western Canadians is to reduce the powers of the federal government, which they do not control, and to increase the powers of the provincial governments, which they do control.

The provinces already have very extensive legislative powers, mainly as the result of the broad interpretation which the courts have given to the phrase "property and civil rights in the province" in s.92(13) of the B.N.A. Act. Some of the federal Parliament's ostensibly large powers have been little used, at least in recent years (disallowance under s.90; declaratory power under s.92(10)(c); redress of educational grievances under s.93), and others have been given a narrow interpretation, at least in contrast with the powers of the United States Congress (peace, order, and good government under s.91's opening words, trade and commerce under s.91(2)). In this way the Canadian confederation has already evolved into a much less centralized system than the literal language of the B.N.A. Act would suggest. ${ }^{5}$

Nevertheless, there is still an agenda of items upon which formal constitutional change has been actively considered in recent years. In the cultural area these include transferring to the provinces some aspects of control over telecommunications, especially cable television, and transferring marriage and divorce to the provinces. In the resource area these include transferring to the provinces the power over indirect taxation of resource revenues, some powers over the interprovincial and international trade in resources, responsibility for fisheries, and transferring ownership of offshore resources to the coastal provinces. Other reform proposals include: limiting the federal peace, order, and good government power over emergencies and over matters of national concern, and transferring the residue of legislative power to the provinces; limiting or abolishing the federal declaratory power; and limiting the federal spending power.

It has proved very difficult for the Prime Minister and premiers to agree on a list of matters which could be transferred to the provinces. Superficially, the problem appears to be the refusal of the federal government to reduce its own powers by acceding to provincial demands. Certainly, that is a big part of the problem, which will be discussed later in this paper. But, as well, it must be conceded that there are serious difficulties in a major decentralization of governmental power in Canada.

First of all, the provinces differ in their aspirations. The concerns of French Canadians focus on language and culture. The concerns of western 
Canadians and to a lesser extent eastern Canadians focus on resources. About the only common thread linking all the provinces would be a desire for more power to control the province's economic development, but even here provincial governments would differ markedly in their assessment of what could properly be left to federal policies.

Secondly, the provinces differ in their capacities. The size and wealth of the provinces differ enormously. ${ }^{6}$ The smaller provinces lack the capacity to increase their responsibilities to any great extent. Moreover, they have reason to resist any substantial diminution of federal power and influence. They are dependent on the federal funding of equalization and shared-cost programmes to maintain the standard of living of their residents. They are also dependent upon the federal government for protection from the unintended adverse effects of the policies of other provinces, for example, energy prices. ${ }^{7}$

Thirdly, there is a concern that the process of decentralization can go too far. At some undefined point the effectiveness of a central government could be seriously compromised, and popular identification with the nation as a whole could be seriously diminished. The decentralization of powers has the rather frightening aspect of a leap into the dark since Prime Minister Trudeau's oft-repeated claim that Canada is already the most decentralized federal country in the world is probably true. Certainly, in both legal and political terms, the legislative and fiscal powers of the Canadian provinces relative to the central government are much greater than those of the American states or Australian states relative to their central governments. In proceeding down the path of decentralization Canadians are denied the comfort of knowing that others have made the journey successfully before.

Fourthly, proposals for increases in the powers of the provinces inevitably invite counter-proposals from the federal government. A charter of rights would perhaps fall into this category. ${ }^{8}$ But, as noted earlier, federal power is not clear and may well be deficient in one area which is generally accepted as an appropriate sphere of federal responsibility, namely, competition policy.

6. A union of the Maritime provinces would help to equalize the size of the provinces, but it seems unlikely to occur in the foreseeable future.

7. "Special status", under which one or more provinces could have different powers than the others, is a possible answer to the differing aspirations and capacities of the provinces. However, special status raises difficult questions about the role in the central institutions, especially the federal Parliament, of the representatives of the province (or provinces) enjoying special status. It seems wrong that they should participate in decisions which in their province are a provincial responsibility. Yet their participation may be necessary to retain a government majority. Political scientists have not yet found answers to these questions.

8. The argument is sometimes made that an increase in provincial powers should be accompanied by the adoption of a charter of rights on the ground that the provinces, being smaller, more homogeneous units than the federal government, will tend to be less tolerant of their minorities than the federal government. And it is, of course, true that several of the provinces can find in their history a chapter of discrimination against a minority of Frenchspeakers, or Chinese or Japanese immigrants, or political or religious dissenters. The difficulty with the argument is that the federal government's record is about equally blemished, especially in times of war (Japanese-Canadians case) or "apprehended insurrection" (FLQ crisis of October 1970), or where "national security" is thought to be at stake (RCMP abuses). 
In several other areas the federal presence is more controversial, namely, foreign ownership, securities regulation and wage and price controls.

The assembly of a package of changes which responds so successfully to all these conflicting concerns that it is acceptable to all Canadian governments is an extraordinarily difficult task. It is only realistic to acknowledge that a substantial alteration of the division of powers in the Canadian constitution is neither practicable nor desirable.

\section{CENTRAL INSTITUTIONS}

\section{A. Intrastate federalism}

A different approach to constitutional change concentrates on reforming the institutions of the federal government so that regional attitudes and interests are more effectively represented within those institutions. The theory is that "the more effectively these attitudes and interests are represented within the central institutions the wider the range of powers which may be conferred on such institutions". ${ }^{\circ}$ If French Canadians and western Canadians could be confident that their interests would be fairly accommodated in the development of federal policies, then, so the argument goes, they would have less reason to demand that powers be transferred from federal institutions to provincial institutions. Thus, the reform of central institutions becomes an alternative to decentralization of powers as a means of redressing regional grievances. This approach to constitutional change has been dubbed "intrastate federalism" by political scientists - in contrast to "interstate federalism", which involves the decentralization of powers. ${ }^{10}$

\section{B. Senate}

The most popular application of intrastate federalism by constitutional reformers has been to the Senate, the upper house of the federal Parliament. Most reform proposals have advocated changes in the Senate. The proposals differ markedly in detail and in nomenclature, but the general idea, modelled on West Germany's upper house (the Bundesrat), is to convert the Senate into a "House of the Provinces" with members appointed by provincial governments. This would then become the means by which provincial governments could exercise a direct influence over federal policies.

One of the attractions of upper house reform is that the representation of regional interests is regarded as a function of the second chamber in other federal systems, and the Senate was originally intended to serve a function of this kind. ${ }^{11}$ Its membership was drawn equally from the three original regions of Canada, namely, Ontario, Quebec, and the Maritime provinces. The West later became a fourth region. ${ }^{12}$ The plan was to offset representa-

9. Donald V. Smiley, "Central Institutions" (1981), paper prepared for the Project on Constitutional Change undertaken jointly by the Osgoode Hall Law School, York University and the Faculté de Droit, Université de Montréal, not yet published, at 2.

10. The paper cited in the previous note is an excellent analysis by a political scientist of intra. state federalism in Canada.

11. R. L. Watts, "Second Chambers in Federal Political Systems" in 2 Ontario Advisory Committee on Confederation, Background Papers and Reports (1970) 315.

12. British Columbia argues that the West is two distinct regions, namely, the Prairie region (Alberta, Saskatchewan and Manitoba) and the Pacific region (British Columbia), and that Senate representation (as well as membership of the Supreme Court and any amending formula) should recognize five, not four, regions. This case is very persuasively made in British Columbia's Constitutional Proposals, supra n. 3, Paper No. 2. 
tion by population in the House of Commons by equality of regions in the membership of the Senate. With hindsight we can see that this plan was fatally flawed because the Senators were to be appointed rather than elected, and to be appointed by the federal government rather than by provincial governments. In any event, the Senate has never been an effective voice of regional or provincial interests.

Whether it is now feasible to reform the federal upper house so as to restore the original plan is doubtful, at least without substantial change in our system of government. The difficulty is that in a system of responsible government the cabinet is responsible to the House of Commons, not to the Senate (or other upper house). If government policy is defeated in the House of Commons, then the government must resign and make way, either for a new government which can command the support of the House of Commons, or for an election which will provide a new House of Commons. An upper house has no obvious place in this scheme of things. That is why in so many jurisdictions with parliamentary systems the upper house has been abolished or reduced to impotence. And that is why the assertions of independence by the Australian Senate which led to the dismissal of Prime Minister Whitlam in 1975 were so bitterly controversial in that country. An independent upper house could block major governmental policies, could refuse to vote supply to the government (which is what the Australian Senate did), and could eventually bring the government down (as occurred in Australia), and yet an upper house appointed by the provinces would not be accountable to the people for its actions. Do we really want to subject our federal governments to the risk of this kind of obstruction?

The reform proposals avoid the risk of major obstruction by also proposing limitations on the powers of any new upper house. The powers would be divided into two categories: category $\mathrm{A}$, into which most legislation would fall, would be only a power of delay; and category B, which would include only matters judged to be of great importance to the provinces, would be an absolute veto. The kinds of matters subject to the absolute veto would be: appointments to the Supreme Court of Canada and major federal administrative agencies; proposals to amend the constitution; exercises of the declaratory power; and exercises of the spending power in areas of provincial jurisdiction. To the extent that the absolute veto power is enlarged, so also is the capacity of the House of the Provinces to obstruct government policy. ${ }^{13}$ To the extent that the absolute veto power is limited, so also is the capacity of the House of the Provinces effectively to assert regional and provincial interests, although no doubt even the delaying power would provide some measure of influence.

\section{House of Commons}

The basic complaint against the House of Commons by regional minorities is that representation by population leaves them subject to the tyranny of the majority. So long as we believe in a democratic system in which each person's vote is equal the position of regional minorities in the House of Commons cannot be radically improved. It is arguable, however, that our

13. Weiler, supra n. 1, criticizes proposals for a House of the Provinces on the ground that the capacity of the federal government to manage the economy would be weakened by the proposals. 
electoral system has exacerbated the problem, and that the representation of regional minorities in the House of Commons could be somewhat improved by reform of the electoral system.

The representation of regional minorities in the House of Commons is affected by the fact that the regional diversity of Canada has come to be reflected in the popular support for the major political parties. The Liberal Party consistently attracts the support of a large majority of French Canadians and a small minority of western Canadians. The Progressive Conservative Party consistently attracts the support of a large majority of western Canadians and a small minority of French Canadians. The electoral system tends to exacerbate the regional character of the parties. The effect of the single-member, majority-vote constituency system is that a minority party whose supporters are spread fairly evenly across constituencies may fail to be the first past the post in any constituency and hence may fail to elect any members of Parliament. For this reason the Liberal Party tends to elect very few members from west of Ontario (it elected two in the last (1980) federal election), and the Progressive Conservative Party tends to elect very few members from Quebec (it elected one in the last (1980) federal election). In practice this skewed electoral result has worked in favour of French Canada because it is the Liberal Party, with its disproportionate representation from Quebec, that has won most federal elections since 1896. (As an aside it may be noticed that the disproportionate representation of French Canadians in federal government caucuses and cabinets over such a long period of time casts doubt upon the whole theory of intrastate federalism, for it has not stopped the rise of Quebec nationalism which has steadily increased in intensity culminating with the election of a separatist party in 1976 and a $40 \%$ vote for the negotiation of sovereignty-association in 1979). It is western Canada which has been virtually shut out of successive federal governments by the skewed electoral results, and it can hardly be doubted that federal economic policies have on the whole tended to favour the manufacturers and consumers of central Canada at the expense of western Canada.

It is arguable that this problem is best resolved by political means. The Progressive Conservative Party has every incentive to build a base in Quebec and turn itself into a truly national party. It would then be a much more serious opposition to the Liberal Party which would in turn be forced to broaden its own political base by developing policies more congenial to western Canada. It is difficult to understand why these developments did not occur long ago. ${ }^{14}$

Since the political parties have not been able to accommodate regional interests, political scientists have recently suggested that a reform of the electoral system would mitigate the problem. ${ }^{15}$ The proposed reform is the introduction of partial proportional representation into elections to the House of Commons. No one seriously advocates the abolition of single-

14. The explanation usually given for the failure of the Progressive Conservative Party's efforts to achieve substantial support in Quebec is French-Canadian resentment over the hanging of Riel by the Conservative government of John A. Macdonald, and over Conservative pressure for conscription in the two world wars. These events occurred a long time ago.

15. The most comprehensive study is W. P. Irvine,Does Canada Need a New Electoral System? (1979). 
member constituencies, but the proposal is that a portion of the seats in the House of Commons would be filled on the basis of proportional representation. ${ }^{16} \mathrm{~A}$ bewildering variety of schemes has been suggested by political scientists to accomplish this result, but they all depend upon the proposition that if several members are elected from a province or region by proportional representation significant minority parties are bound to secure new members. This would ensure that each major party had representation in the House of Commons from all major regions of the country. Through proportional representation some Liberals would be elected from the West and some Conservatives from Quebec; these individuals, it is argued, would become spokesmen for their regions in the caucus of their party and, if the party was in power, in the cabinet.

Although not qualified to comment on these proposals for electoral reform, I shall make some brief comments. One is that the reform does address itself to the existing centres of federal power, namely, the House of Commons and the cabinet. It lacks the boldness of upper house reform, which seeks to transform a weak institution into a powerful one, but it also lacks the risk of failure which is inherent in all attempts to alter longstanding institutions. However, the assured success of the partial proportional representation plan is a very modest success. All that will indubitably follow is the introduction into the major party caucuses of a few extra members from regions now badly under-represented. The fact that most members will still be elected from single-member constituencies ensures that the electoral results will still be quite badly skewed. Moreover, it is hard to know what calibre of person will secure a place on his party's list, and whether those elected by proportional representation (who will lack constituencies) will be perceived by the Prime Minister and their colleagues as second-class members. Finally, the increased representation of minority parties will slightly increase the risk of minority governments. This last criticism is not very strong because the present system does not deliver majority governments with impressive regularity: of the eleven federal general elections between 1957 and 1980 inclusive only five have produced majority governments. We have thus grown accustomed to the likelihood of minority government, and some of us have even come to find merit in it.

\section{Supreme Court of Canada}

The Supreme Court of Canada is the other central institution to which the idea of intrastate federalism has been applied in recent reform proposals. The composition of the court already reflects Canada's regional and linguistic differences. The Supreme Court Act stipulates that three of the nine judges must be appointed from Quebec. By convention the remaining six judges have been appointed as follows: three from Ontario, two from the four western provinces, and one from the Atlantic provinces. This distribution did not recognize British Columbia as a distinct region, which has been a central (and plausible) tenet of British Columbia's constitutional aspirations, ${ }^{17}$ and in 1978, on the retirement of a judge from Ontario (Spence

16. Of the official reform studies (see $n$. 3), only the Task Force on Canadian Unity (pp. 104-106) has made this recommendation, although the Constitutional Committee of the Quebec Liberal Party (pp. 46-47) recommended that the proposal be studied.

17. See supra n. 12. 
J.), a judge from British Columbia (McIntyre J.) was appointed. This altered the pattern of appointment which had been consistently adhered to since 1949 when the court's composition was raised from seven to nine judges.

The nature of the judicial function, as understood in Canada and other countries in which the judiciary is independent, does not allow a judge to "represent" the region from which he was appointed in any direct sense, and certainly does not allow the judge to favour the arguments of persons or governments from that region. What regional representation does do, however, is to ensure that there are judges on the court who are personally familiar with each major region of the country, and who can bring to the decision of a case from that region an understanding of the region's distinctive legal, social and economic character. When the court does not sit as a full bench one finds that the judge or judges from the region from which each appeal originated are nearly always assigned to that appeal; and that one of those judges will usually write the opinion of the majority. Many criticisms have been levelled at the Supreme Court of Canada, but I do not think it has ever displayed the ignorance of Canadian ways of which the Privy Council was occasionally guilty.

The regional composition of the court must enhance the sensitivity and acceptability of its opinions, but the structure of the court has still attracted some strong criticisms which reveal considerable discontent, especially in Quebec and western Canada. ${ }^{18}$

The first point of criticism is that the court's existence and jurisdiction are not guaranteed by the B.N.A. Act. The court's existence and jurisdiction depend upon the Supreme Court Act, which is a federal statute enacted under s.101 of the B.N.A. Act. As a matter of strict law, therefore, the court could be abolished or radically altered by the federal Parliament. Of course, this is not a practical possibility. Nevertheless, all the reform studies agree that the existence and jurisdiction of the court should be entrenched in the constitution so that the court is outside the reach of federal legislative power. While this proposal is uncontroversial, it should be noticed that its wise implementation will be quite difficult. The matters dealt with in the constitutional text will become unchangeable except by constitutional amendment. That is the whole point of the exercise. But if too much detail is incorporated in the constitutional text then the kinds of incremental change in the composition or powers of the court which have occurred in the past will become exceedingly difficult in the future.

A second criticism of the structure of the court is that the judges of the court are appointed solely by the federal government. All the reform studies argue that the provinces should play a role in the selection of judges to the court. This can be accomplished either by giving to each provincial government (for example, the provincial Attorney General) a direct role in the selection of a judge from that province, or by giving to provincial governments an indirect role by requiring ratification of federal selections

18. The most comprehensive study of proposals to reform the Supreme Court of Canada is James C. MacPherson, "The Potential Implications of Constitutional Reform for the Supreme Court of Canada" (1981), paper prepared for the Project on Constitutional Change undertaken jointly by the Osgoode Hall Law School of York University and the Faculté de Droit, Université de Montréal, not yet published. 
by a new House of the Provinces. The former method has the potential to be rather complex and time-consuming and to subject judicial appointments to a process of intergovernmental bargaining which may well not yield the best candidate for the position. Still, it cannot be rejected out of hand since it is essential that provincial governments should have complete confidence in the court. If the initial selection continued to be made by the federal government alone, a provincial role can still be provided by a process of ratification by a House of the Provinces or other legislative body or committee upon which the provinces are represented.

A third point of criticism is that there are too few judges from Quebec on the court. As noted earlier, the present position, mandated by the Supreme Court Act, is that three of the nine judges must come from Quebec. The argument that three is too few depends upon an evaluation of the court's capacity to decide three classes of cases: (1) those in which the record and argument are in the French language, (2) those raising issues of civil law, and (3) those raising constitutional issues. The argument for increased representation from Quebec is quite strong with respect to the first two classes of case. The judges from Quebec would have a perfect fluency in French and a familiarity with the civil law which the judges from outside Quebec would often lack. ${ }^{10}$

The argument that there should be more judges from Quebec to decide constitutional cases is not as strong. This argument, which has naturally tended to come from Quebec commentators, depends upon the premise that Quebec has a special stake in the outcome of constitutional controversies. With respect to some issues that premise is correct. Issues of culture and language, such as those raised by the recent cable television and language cases, probably do have a deeper impact in Quebec than elsewhere. But with respect to other issues that view is incorrect. Issues of resource ownership or control are of much greater interest to the western provinces and (in the case of offshore resources) coastal provinces than they are to Quebec. Many other issues, for example, those relating to consumer protection or economic development, while they are of great importance in Quebec, have an equally significant impact in other provinces. It seems, therefore, that for many constitutional issues a larger complement of judges from Quebec (and therefore a relatively smaller complement from the other parts of the country) would not lead to better informed decision-making, and might even lead to resentment in the under-represented parts of the country. I conclude that the case for larger Quebec representation on the court should turn on the capacity of the court to handle French-language and civil-law cases, rather than on the capacity of the court to handle constitutional cases.

If it is agreed that there should be more judges from Quebec on the court, the details of that change are still difficult to work out. Any increase in Quebec's numbers involves either a decrease in the numbers drawn from

19. In view of the fact that the court's composition changes no generalization can be absolutely correct. But I think it is fair to speculate that the judges from outside Quebec, while they would no doubt always be able to read and understand French, would not usually be sufficiently fluent to play an active part in oral argument. Certainly, it must be rare that a judge from outside Quebec would have received training in the civil law or would have been extensively exposed to it in practice. The converse would not usually be true, that is to say, the judges from Quebec would usually be fluent in English and would usually be familiar with common law modes of reasoning. 
other regions or an increase in the size of the court. The former alternative is particularly hard to defend. It seems unlikely that the western provinces would agree to reduce their representation on the court, since they have been especially critical of the court's treatment of resource-related issues. The Atlantic provinces have only one judge anyway. That leaves Ontario. If Ontario were to give up one of its three judges to British Columbia (as may already have happened) and another to Quebec, only one judge would be drawn from the province which contains the largest number of lawyers and a very sophisticated bar. That would seem to be an unwise limitation of the selection process. The other way of increasing the number of judges on the court from Quebec would be to increase the size of the court to eleven, thus providing two more places to allocate. This would enable Quebec's representation to be increased to four or five, depending upon whether Ontario should be "given back" the place now filled from British Columbia. This may be the best answer, although as the court increases in size there are risks to the quality of the oral argument before the court and to the collegiality of the court, which may lead to more fragmentation and more delay in the court's decisions.

Finally, in proposals to restructure the Supreme Court of Canada, it has occasionally been suggested that there should be a special constitutional court, or a special constitutional panel of the present court, to decide constitutional cases. This suggestion has not been accepted by any of the recent reform studies. ${ }^{20}$ Support for this proposal has often come from Quebec and has been premised on a dualist view of Canada under which constitutional issues should be determined by a tribunal upon which French Canada has an equal voice with English Canada. ${ }^{21}$ As noted earlier, this is a dubious proposition having regard to the range and variety of constitutional issues which have as much or more impact on provinces other than Quebec. To the extent that the proposal for a constitutional court is premised on the desire to assemble a broader range of talented individuals (not necessarily lawyers) to decide constitutional cases, ${ }^{22}$ it involves the risk of creating an active policymaking body which is not amenable to any of the processes of democratic accountability. And, as a technical matter, there is good reason not to try to decide constitutional issues in isolation from the other elements of a justiciable controversy which supply the context and colour and are in my view indispensable to wise constitutional decision-making. My conclusion is that judicial review should continue to be the function of the same Supreme Court of Canada that serves as a general court of appeal for Canada. ${ }^{23}$

20. The Government of Alberta in Harmony in Diversity, supra n. 3 at 11, has advocated that constitutional cases be withdrawn from the Supreme Court and entrusted to a bench of seven judges drawn at random from a panel of forty or fifty judges of provincial superior courts. The Constitutional Committee of the Quebec Liberal Party, A New Canadian Federation (1980) 58-60, proposes that "on request" a constitutional case should be submitted to "a dualist constitutional bench composed of an equal number of judges from Quebec and from the other provinces".

21. See J. Y. Morin, "A Constitutional Court for Canada" (1965) 43 Can. Bar Rev. 545; and see the proposal of the Constitutional Committee of the Quebec Liberal Party, supra n. 20.

22. See Paul C. Weiler, "What the Supreme Court is Doing to the Constitution and What Constitutional Reform May Do to the Court", Ladner lecture delivered at the University of British Columbia, 1980, not yet published.

23. Accord, MacPherson, supra n. 18 at 35-38; Hogg, supra n. 2 at 48. 


\section{CHARTER OF RIGHTS}

Since the Second World War it has become widely accepted that a nation's constitution should include protections for minority rights and other civil libertarian values. A charter of rights has therefore become an indispensable part of the constitution of each of those countries which have attained independence since then. Naturally, the absence of extensive bill-of-rights guarantees in the B.N.A. Act has attracted the attention of reformers. Most of the recent reform studies have recommended the adoption of a charter of human rights, binding on both the federal government and the provincial governments.

The desirability of a bill of rights is a difficult issue, involving assessments of the relative capacities of the political institutions and the courts to resolve civil libertarian issues in ways that will respect civil libertarian values without frustrating social change. I do not propose to add to the mountain of literature on that topic. ${ }^{24}$ However I do wish to emphasize the implications of a charter of human rights for federal-provincial relationships.

An effective charter of rights will limit the powers of both levels of government and in that sense will not change the balance of power within Confederation. On a subtler analysis, however, it seems that a charter of rights is a centralizing influence. The institutions to which a charter of rights inevitably accords extra power are the courts and therefore ultimately the Supreme Court of Canada. Issues that are now decided conclusively by the federal Parliament or the provincial Legislatures would become subject to review by the Supreme Court of Canada. If the charter of rights includes guarantees of equal protection, of mobility from province to province, and of language rights, then a very important range of decisions now within provincial responsibility will become subject to review by the Supreme Court of Canada. One need only look south to the United States to see how deeply the decisions of the Supreme Court have penetrated all of the major policies of that country, many of them otherwise within state jurisdiction. In addition, the existence of national rights which can be invoked against provincial Legislatures encourages individuals to think of themselves as part of a Canada-wide community, looking to a national court for redress of grievances even in areas of provincial jurisdiction..$^{25}$

Language rights are the arena in which this view of Canada comes into its sharpest conflict with the view which emphasizes provincial autonomy. Proponents of a charter of rights would say that it is a constitutional imperative that French-speaking and English-speaking Canadians should be able to move freely throughout the country, relying on national language rights to assure some recognition of their language at least in governmental and educational institutions. Opponents would argue that provincial responsibility for the enactment of laws, the supply of public services, the administration of justice and education should include the power to stipulate the language in which those functions are performed. Similar competing arguments may be made on the question whether the provinces should retain the power to

24. My views are set out in Hogg, supra n. 2 at 432-434.

25. Alan C. Cairns, "Recent Federalist Constitutional Proposals" (1979) 5 Can. Public Policy 348 at 354. 
impose occupational, landholding, and commercial restrictions on nonresidents. At bottom the question is whether Canadian citizenship should carry with it equal opportunities throughout the country - monitored by the Supreme Court of Canada - or whether each province should be free to establish a distinctive linguistic, social and economic regime which best suits its own majority. From the standpoint of federalism, these are the kinds of questions which are raised by the proposal for a charter of rights.

\section{PATRIATION AND AMENDMENT}

\section{A. Patriation}

The "patriation" of the constitution is important for symbolic reasons, but by itself it is of no significance to the balance of power between centre and regions. However, if the ties with the United Kingdom were irrevocably cut, and no other constitutional changes were made, there would be no way of amending the B.N.A. Act. The substantive significance of patriation, therefore, is that it has to be accompanied by the inclusion in the constitution of an amending procedure which would enable the constitution to be amended without recourse to the United Kingdom.

\section{B. Amendment}

It is a notorious fact that Canadian governments have been trying to find an amending formula without success since 1927. A major difficulty has been the process by which the search has been undertaken. An assumption has developed that the adoption of an amending formula - any amending formula - should be accompanied by other changes in the constitution. The amending formula has thus come to be regarded as just part of a package of constitutional reforms. Needless to say, securing agreement on a package of reforms is much more difficult than securing agreement on a single matter, such as an amending formula. Exacerbating the package problem has been the further assumption, shared until recently by the federal government as well as the provinces, that no package of amendments should be proceeded with unless it was unanimously agreed to by the federal government and all the provincial governments. ${ }^{26}$ Thus the dissent of even one provincial government would mean that a proposal for amendment could not be proceeded with.

In 1964 agreement was nearly reached on the Fulton-Favreau formula. That formula would have required the unanimous consent of the provinces, as well as the federal government, for important amendments. Despite the requirement of unanimity, which would have given Quebec (or any other province) a veto over future changes, Quebec did not agree to this proposal and it was not pursued. ${ }^{27}$ In 1971 agreement was nearly reached on the Victoria charter formula. That formula would have required the agreement of a majority of provinces to amendments; but the majority had to include (1) any province which had at any time at least 25 per cent of the population of

26. Note 4, supra, records a major constitutional initiative undertaken unilaterally by the federal government after unsuccessful attempts to achieve agreement with the provinces on a package of changes.

27. E. A. Forsey, Freedom and Order (1972) 235-237. 
Canada (this preserved a veto for Quebec and Ontario even if their relative populations subsequently declined), (2) at least two of the Atlantic provinces, and (3) at least two of the Western provinces that have combined populations of at least 50 per cent of the population of all Western provinces. Despite the requirement of Quebec's consent, Quebec did not agree to this proposal and it was never pursued. ${ }^{28}$

Since 1971 it has become clear that the Victoria charter formula no longer enjoys the support of some of the provinces which agreed to it in 1971 . British Columbia objects to the formula on the ground that it does not recognize British Columbia as a region of Canada (the Pacific region) separate from the prairie provinces (the Prairie region) ${ }^{29}$ If the formula were amended to require the consent of British Columbia then it would be acceptable to British Columbia. ${ }^{30}$ However, Alberta objects to the fact that the formula accords greater recognition to Ontario, Quebec and (if British Columbia gets its way) to British Columbia than it does to Alberta. In Alberta's view, "an amending formula must reflect the principle that all provinces have equal constitutional status and that an amending formula [must]reflect the principle that existing rights, proprietary interests and jurisdiction of a province cannot be diminished without the consent of that province". ${ }^{31}$ The general idea seems to be that every province should have the right, if not to block a proposed amendment, at least to prevent that amendment from applying to it.

Despite the collapse in support for the Victoria charter formula, most of the constitutional reform studies have advocated its adoption as Canada's amending procedure. The widespread view has been that it avoids the straightjacket of unanimity while still assuring that any amendment has substantial support in each part of the country. No doubt this is why the Victoria charter formula is included in the federal government's current constitutional proposals. ${ }^{32}$

\section{THE REFORM PROCESS}

\section{A. The present process}

A basic fault in both the present process of seeking agreement to constitutional amendments and the various new amending formulae which have been proposed is their reliance on existing institutions of government. Whether an amending process calls for the consent of a provincial Legislature or a provincial government, the reality is that it must be acceptable to the government of that province. That means, of course, the Premier and his cabinet. If the process requires the consent of the federal Parliament or the federal government (as all proposed processes do), that means that it must be acceptable to the Prime Minister and his cabinet.

28. Id. at 237-238.

29. Supra n. 12.

30. Government of British Columbia, British Columbia's Constitutional Proposals (1978) 99-104.

31. Government of Alberta, Harmony in Diversity (1978) 18-19.

32. Constitution Act, 1981, s. 45, as proposed in Proposed Resolution for a Joint Address to Her Majesty the Queen respecting the Constitution of Canada; supra n. 4. 
So long as constitutional reform remains the preserve of the Prime Minister and the ten premiers, there are many matters that cannot even be placed on the agenda, let alone agreed to. For example, there is a body of serious opinion to the effect that our system of responsible parliamentary government now gives too much power to the Prime Minister or Premier who heads a government. The position of the President or a Governor in the United States is the obvious comparison. Yet in all the discussion of central institutions, there has been no proposal to diminish the powers of the Prime Minister (or Premier) vis-à-vis the legislative body to which he is responsible. Such a proposal cannot even be discussed in Canada outside academic journals because all participants in the constitutional reform process have a vested interest in resisting such a change. In other words, when constitutional change must be initiated and agreed to by those who already wield the bulk of political power there is a powerful reinforcement of the status quo. It has been instructive to notice how vehemently the provincial premiers have opposed the current federal plan to introduce the referendum as an alternative amending procedure. ${ }^{33}$ This plan would remove the premiers from that procedure. Of course, the Prime Minister would be equally opposed to it if the referendum could be initiated by some body other than the federal Parliament which he controls. The fact is that the present participants in the constitutional reform process are unlikely to agree to any significant restructuring of governmental institutions. This is a serious constraint on the process.

What each participant is willing to agree to are constitutional changes which would enhance that participant's status or powers. However, such changes normally involve some diminution in the status or powers of another participant. This leads to a process of bargaining between Premiers and Prime Minister which looks a lot more like labour-management negotiations than the drafting of a constitution. Unlike labour-management negotiators, however, the participants to constitutional discussions do not have a sufficiently powerful incentive to reach agreement, and so agreement never is reached. Perhaps this is just as well since it is hard to feel confidence in a constitutional text (which has to last for a lot longer than a collective agreement) arrived at by such methods.

\section{B. Initiative and referendum}

My own view, which I offer without the slightest expectation of its being accepted by any political office-holder, is that we should adopt the old western idea of "initiative and referendum". ${ }^{34}$ One mode of constitutional amendment - not the only mode, but one mode - should be some form of initiative and referendum, under which a proposal for a constitutional amendment could be initiated by petition signed by a stipulated (fairly large) number of voters, and could be adopted by a referendum which obtained majorities in each region of the country. What I have in mind is a procedure which could by-pass entirely the existing political office-holders.

33. Id. at s. 46.

34. For discussion of the legal issues raised by the initiative and referendum law-making process, as it was adopted in Alberta and Manitoba early this century, see Hogg, supra n. 2 at 218-223. 
It will no doubt be argued that Canadian experience with referenda or plebiscites (as non-binding popular votes are more properly described) has not been particularly happy, because they tend to be divisive. The only evidence for that proposition is the conscription referendum of 1940, where conscription was carried by a large English-speaking majority despite French-speaking opposition. But not many issues have the potential to divide the country like conscription. In any case, my proposal, like the present federal proposals, would be that the referendum would have to carry in each region in order to be effective. There would be no question of some parts of the country using their votes to force through an amendment that was unacceptable to other parts of the country.

Apart from the conscription question, surely the referendum has been perfectly satisfactory as the way to decide fundamental questions. That is how the United Kingdom resolved its question whether to remain in the European Economic Community. That is how Newfoundland decided to enter Confederation. That is how Quebec rejected separatism. And that is how Australia and Switzerland amend their constitutions. ${ }^{85}$

The advantage of the referendum procedure would be that a single constitutional proposal could be put forward and voted on without the necessity of a prior agreement by all the governments to an entire package of amendments. Under a referendum procedure, a desirable reform measure could be examined on its own merits, instead of being treated as a bargaining counter in a broader set of negotiations. It is not as if governments would be excluded from the process. They could, and no doubt would, campaign for or against any particular proposal, ${ }^{36}$ but the campaign would have to be addressed to the merits of the particular proposal. Support or opposition could no longer be simply a bargaining ploy, because that obviously would not persuade the voters.

The ability to put up a single proposal for amendment would exist under the federal government's present proposals. But the trouble with these is that the federal government is the only body with authority to initiate the referendum process. It seems obvious that a provincial government, or at least a group of provincial governments, should also have the power to initiate the process - without federal consent. What I am recommending now would go one step further than that by permitting the process to be initiated by citizens. I would anticipate that a large number of signatures

35. In Australia, the process must be initiated by the federal Parliament; there is no provision for a popular initiative: Constitution of Australia, s. 128. In Switzerland, the process can be initiated either by the federal Assembly or by popular initiative. For a brief summary of the Swiss amending process, see Government of Canada, The Canadian Constitution and Constitutional Amendment (Federal-Provincial Relations Office, 1978) 4-5.

36. This is what happens in Australia, where state governments will often campaign against a constitutional amendment which is supported by the federal government. The Australian experience should also allay any fear that the federal government, with its large resources, will always be able to win any referendum. In Australia since federation in 1900, 28 referenda have been held, embracing 50 proposed amendments, each of which was supported by the federal government (which must initiate the process). Only six of the referenda, embracing nine amendments, have carried by the required "double majority" (a majority of all those voting, and a majority of those voting in each of a majority of states): Christopher D. Gilbert, The Globe and Mail, December 13, 1980. A Canadian referendum, if it required (as it should) a quintuple or sextuple majority (a majority of all those voting, and a majority of those voting in each of four or five regions), would be even harder to win. 
would be required to ensure that there was widespread support for the proposal.$^{37}$ Even so, it is possible that there would be some silly proposals, but of course they would not carry. ${ }^{38}$ The big advantage is that the procedure would be available in support of proposals to amend the constitution which were being blocked by the intransigence of executive-dominated governments. It would mean that the ultimate control over the amending process would rest where it ought to rest - with the people.

37. Switzerland requires 100,000 signatures: supra n. 34 .

38. The expense of a lost referendum would not be entirely wasted if it tended to defuse the issue by allowing proponents a "day in court" and demonstrating the extent of their popular support. 